\title{
Introduction: Listening to Antarctica
}

\author{
Tom Griffiths ${ }^{1}$
}

In 2011, we commemorated a series of Antarctic anniversaries: the centenary of Douglas Mawson's Australasian Antarctic Expedition, 100 years since the attainment of the South Pole, 75 years since the coming into force of the Australian Antarctic Territory and 50 years since the ratification of the Antarctic Treaty. On planet Earth today, it could be said that we inhabit the Antarctic moment. Each year now, tens of thousands of tourists visit a realm that, just a few generations ago, was virtually unknown. Over the past century we have learned just how different is the Antarctic from the Arctic, and Antarctica has moved from the geographical periphery of our consciousness to the centre of our scientific and intellectual concerns. The physics and politics of global warming have turned our eyes towards the great southern ice cap, which has 90 per cent of the world's land ice and 70 per cent of the globe's fresh water. The same industrial capitalism that has unleashed carbon has given us a planetary consciousness that reveals a calving berg as not just a random, local act of nature, but instead as the frightening frontier of a possibly irreversible global, historical event. Understanding ice - its history and its future - has turned out to be a key to understanding climate change and to securing a human future. The great white continent has never before gripped our imagination or dictated our destiny with such power.

It is a great pleasure to contribute to this volume, which follows a wonderful Antarctic Music Festival in Canberra in 2011 involving so many talented thinkers and performers. This event stimulated us to consider what it is that constitutes the culture of the ice. It also reminded us that Antarctica presents a cultural challenge to us, as well as a scientific and political one. How are we to make sense of such a remarkable, otherworldly part of the planet? How are we to imagine and experience it; how are we to respond ethically and emotionally to it; how are we to depict or distil it; what social and cultural experiments does it demand; what stimulus to human hope and creativity might it offer; what sensations, insights and ideas might it foster? Antarctica does not only prompt logistical, political or intellectual questions; it implicates and challenges our humanity.

The recent Antarctic anniversaries sketch out not just an evolving human engagement with the South Pole, but also a peculiarly Australian story. Voyagers,

1 Professor Tom Griffiths, William Keith Hancock Professor of History, Centre for Environmental History, The Australian University, Canberra ACT 0200, tom.griffiths@anu.edu.au. 
sealers and whalers headed south from colonial ports and, from the 1880s, Australian colonists themselves began to turn an imperial gaze towards the ice. Exploring Antarctica became a proud initiative of the newly federated nation in the early 20th century. Douglas Mawson's Australasian Antarctic Expedition of 1911-14 was part of that assertion of national interest; it was also the most earnestly scientific expedition of the heroic era, and one that put geographical exploration ahead of the race to the pole. That early, unambiguous Australian commitment to the priority of science offers us a proud inheritance, and one that has strengthened in the last 50 years of the Antarctic Treaty era.

After the Great War, Australia exerted strong pressure on Britain to secure sovereignty over the vast region of Antarctica south of Australia. This region was as close to Australia as Hobart was to Fremantle, and Australians felt a growing affinity with, and responsibility for, what was sometimes referred to as our 'Great Frozen Neighbour'. ${ }^{2}$ Throughout the 1920s and 1930s, energetic Australian diplomacy was instrumental in expanding the frontiers of the British Empire into the Antarctic. Australia was no 'passive witness' to imperial events but, instead, acted on a clear conception of its distinctive outlook and material self-interest in Antarctic affairs. ${ }^{3}$ Historian Marie Kawaja at ANU has been doing pioneering research in the diplomatic cables and official memoranda of the National Archives of Australia, and unearthing a new, vital story about the tenacity and expertise that underpinned Australia's political interest in Antarctica from the beginning. ${ }^{4}$ This version of Australian history has been largely overlooked by historians of Australian diplomacy and foreign policy. It reminds us what stirring insights can be dug out of official archives, and also how coming to terms with Antarctica tends to make one see one's country and the world - differently.

Of course, part of the Australian Antarctic story was Douglas Mawson's return to Antarctica in the summers of 1929-31, when he led the British, Australian and New Zealand Antarctic Research Expedition (known as the BANZARE voyages) in Scott's old ship, the Discovery. Mawson's secret instructions from the Australian Prime Minister were to 'plant the British flag wherever you find it practicable to do so'..$^{5}$ The passing of the Australian Antarctic Territory Acceptance Act 1933 by the Commonwealth parliament formalised

\footnotetext{
2 'Our great frozen neighbour'. Adelaide Advertiser, 26 February 1929, NAA: Series A 461/8, Item H413/2, quoted in Marie Kawaja and Tom Griffiths (2011) "Our great frozen neighbour": Australia and Antarctica before the Treaty, 1880-1945'. In Marcus Haward and Tom Griffiths, eds, Australia and the Antarctic Treaty system: 50 years of influence. UNSW Press, Sydney, pp. 9-47.

3 Marie Kawaja (2010) Politics and diplomacy of the Australian Antarctic, 1901-1945. PhD thesis, The Australian National University, Canberra.

4 See Kawaja (2010) 'Politics and diplomacy', and Kawaja and Griffiths (2011) 'Our great frozen neighbour'. 5 WM Bush, ed. (1982) Antarctica and international law: a collection of inter-state and national documents, vol. II, London, Doc. AU12091929, pp. 117-18. See also Phillip Ayres (1999) Mawson: a life. Melbourne University Press, Carlton, p. 173.
} 
the constitutional arrangements that allowed the Australian government to be the controlling authority over the Australian Antarctic Territory, a sovereignty claim for more than 42 per cent of Antarctica.

In the post-war period, a remarkable resolution of Antarctic territorial claims and rivalries emerged in the form of the Antarctic Treaty, which was signed by 12 nations (including Australia) in Washington in 1959, and which came into force in 1961. Just over 50 years ago, the first Antarctic Treaty Consultative Meeting — the annual assembly for Antarctic governance — was held in Canberra in (Old) Parliament House. It is unusual for an international treaty document to mention a city, but the text of the Antarctic Treaty does mention just one, and it is Canberra. Article IX names the City of Canberra as the first place that contracting parties shall meet 'within two months after the date of entry into force of the Treaty'. The choice of Canberra was, in part, recognition of the crucial role played in the treaty negotiations by Australia's Richard Casey.

And so it was that, on a typical Canberra winter morning on 10 July 1961, Prime Minister Robert Menzies welcomed delegates to Parliament House, saying 'As a matter of fact, I thought this morning, as I peered through the fog, that we had gone to some trouble to give you a proper Antarctic welcome.' Senator John Gorton was elected as chairman of the gathering, and Lady Mawson, the widow of Douglas Mawson, was present. Mr Menzies explained to the assembled delegates that Australians 'have a deep sense of neighbourhood about the Antarctic'. The leader of the Norwegian delegation declared: 'We feel that this might be a great stepping stone towards world peace, that examples from this treaty might be embodied elsewhere, and that the spirit of this treaty might prevail in other spheres. ${ }^{6}$ The construction of the Berlin Wall commenced just after the gathering in Canberra in July 1961 and, a year later, the world held its breath during the Cuban missile crisis. People were desperate for a different model of international relations. ${ }^{7}$

The Antarctic Treaty has provided that, and with remarkable success. It arose, like a kind of miracle, out of the tensions of the Cold War, in some senses was created by them. So, in 2011, we commemorated 50 years of the Treaty as well as the Mawson expedition centenary. Mawson died just one year before the Treaty was signed and he didn't foresee it, or even particularly want it. Today we recognise, with hindsight, that the Antarctic Treaty was not only a significant achievement in its own right, but that it was also a precursor, a model for the rest of the world and for the future. It was the first arms control

6 Commonwealth of Australia (1961) Antarctic Treaty. Report of the First Consultative Meeting, p. 30.

7 For further details on the negotiation of the Treaty, see Tom Griffiths (2010) 'The Antarctic Treaty in 1959'. In Australia and the Antarctic Treaty - then and now. IMAS, University of Tasmania, pp. 9-15. 
treaty of the Cold War. ${ }^{8}$ It became an inspiration for the governance of other places - for management of the sea and outer space. As we today confront the global management of climate change and the lingering disappointment of the Copenhagen summit, the Antarctic Treaty offers an inspiring example of how respect for science can constructively inform world politics. ${ }^{9}$

Australia has been a major and positive player in the Antarctic Treaty System, and was, for example, a leader in the political revolution of 1989-91 when Treaty nations abandoned a mining convention and negotiated instead the Madrid Protocol on Environmental Protection. Over the last few years, the political scientist Marcus Haward and I have been working with a range of scholars and practitioners on a book about Australia's influence in the Antarctic Treaty System over 50 years. It was available when Australia hosted the Antarctic Treaty Consultative Meeting in 2012 in Hobart. ${ }^{10}$ The story of Australia's creative engagement in this international political regime deserves to be better known in our own country.

These, then, are some of the political and strategic foundations of Australia's relationship with Antarctica. But what of our cultural relationship to our southern neighbour? The culture of the ice remains one of the least studied aspects of the place, yet understanding of it is vital. Culture, of course, suffuses everything we do and say. It is ineffable and all-pervasive. How should you behave when arriving at an Antarctic station at the end of the polar winter? What is 'the changeover'? Whose ghostly footfalls do you hear when you enter the heroic-era huts? What did it mean to 'pont'? ${ }^{11}$ How close should you get to an Adélie penguin? Where is 'the Daintree of Antarctica'? What is a true wilderness? What could the gift of a pebble imply? How exactly might one claim a tract of ice for one's country? Is it dangerous to be alone? What is a ventifact? Is it wise to disagree openly in a small community? How do you feel when you see green? When should you - and when shouldn't you - use the word 'sovereignty'? These are some of the countless delicate questions whose answers demand immersion in Antarctic culture.

\footnotetext{
8 Rob Hall and Marie Kawaja (2011) 'Australia and the negotiation of the Antarctic Treaty'. In Haward and Griffiths, eds, Australia and the Antarctic Treaty system, p. 91.

9 The 'official narrative' of the Treaty suggests that scientific idealism has largely trumped political rivalry, and equates science with international cooperation. However, this view has been challenged by careful accounts of how the mentality of settler colonialism underpins Antarctic history and continues to operate in subtle and effective ways under the Treaty. See the scholarship of Klaus Dodds, Christy Collis, Adrian Howkins, Peder Roberts, Alan Hemmings and Alessandro Antonello.

10 Marcus Haward and Tom Griffiths, eds (2011) Australia and the Antarctic Treaty system: 50 years of influence. UNSW Press, Sydney.

11 The verb 'to pont' means to pose, in polar discomfort, for a photograph, and is drawn from the name of Herbert George Ponting, photographer on Scott's last expedition. See Bernadette Hince (2000) The Antarctic dictionary: a complete guide to Antarctic English. CSIRO Publishing and Museum of Victoria, Melbourne.
} 
Those who participated in this conference are pursuing this mission - to create and appreciate art, words, music, poetry, sculpture, dance, prose, objects, images, performances that make us think and feel with more perception, understanding and discrimination about a place that seems almost to defy human affiliation and scrutiny. The disciplinary boundaries between art and science melt in the quest for holistic understanding. At the 2011 Antarctica and Music conference, we were lucky to have Tim Bowden capturing Antarctic stories, Bernadette Hince investigating polar words, Rupert Summerson analysing wilderness, Elle Leane reading Antarctic literature, Steve Martin, Heather Rossiter and Mark Pharaoh sifting the legacy of the Australian Antarctic Expedition, Arnan Wiesel and Alice Giles stimulating us to think about Antarctic music. We need this work. The historian Stephen Murray-Smith asserted its importance during a heated debate in the ship's bar on his return voyage from Antarctica in 1986. He challenged his companions: 'Don't you think ideas and ideals are important? I tell you this, if this country has a future in Antarctica it will be because people have ideas about it.' ${ }^{12}$

One view of Antarctic culture is that it has all been about coming to terms with the immensity and meaning of the continent's vast icy outback. Antarctic voyagers of the 19th century had originally wanted rock. They wanted rock and soil they could plant a flag in and claim for their country. The ice was in the way: it was a nuisance, an obstacle. Later, the ice became a testing ground for physical endeavour, a source of beauty and fear, but still essentially an obstruction stopping them from reaching, studying and claiming the land beneath. But by the mid-20th century, the ice itself had become a primary scientific focus and was no longer regarded just as an obscuring and frustrating 'barrier' between visitors and the much-desired land. Scientists began to see ice as a mineral of interest in itself; they began to see glaciers as geological and Antarctica as a vestigial landscape, a giant white fossil.

In the early 1950s, it was discovered that the ice sheets were not just a few hundred metres thick but actually kilometres deep, and so the driest of all continents was actually a vast elevated plateau of frozen water. This startling discovery revealed that world sea level is principally controlled by the state of the Antarctic ice sheet. Questions about the ice changed from how frustrating, to how vast, how continental, how deep, how old, and then to how stable? Recent observable changes in the ice cap became anxiously assessed. The confirmation of global warming due to human influence came not only from the behaviour of the ice sheet, but also from the air bubbles trapped within it. Before Antarctica was even seen by humans, it was recording our impact.

12 Stephen Murray-Smith (1988) Sitting on penguins: people and politics in Australian Antarctica. Hutchinson Australia, Sydney, p. 125. 
If 100 years ago the defining Antarctic journey was the sledging expedition across the surface of the ice, and 50 years ago it was the tractor traverse that, with seismic soundings, measured the volume of the ice sheet, then the defining Antarctic journey of our own era goes straight down, with the help of a drill, from the top of the ice dome to the continental bedrock, a vertical journey back through time. And the ice core thus extracted enables us to see our civilisation in the humbling context of hundreds of thousands of years of climate history. Right now in Antarctica, the international race is on again - not for the South Pole, not for the first trans-Antarctic traverse, but for the first million-year ice core. ${ }^{13}$

The dominant historical narratives of this international continent are nationalist. Nationalism is not contrary to the spirit of the Antarctic Treaty, for national endeavour is the means of contributing to the treaty system and there is national pride in becoming an influential party. But, as well as being a site of international cooperation, Antarctica has generated patriotism and competition, and sectors of the ice sheet have been integrated in distinctive and exclusive ways into dozens of national histories. Argentine and Chilean Antarctic territories appear on those nations' domestic maps; Richard Byrd established a 'colony' at what he called 'Little America'; Amundsen's triumph consolidated early 20th-century Norwegian nationhood; and in Australia, Mawson's huts have been seen to be 'as much a part of the national psyche as the Hills Hoist, Uluru, [and] the Eureka Stockade'. ${ }^{14}$ Antarctic scholars have been wary of embracing postcolonial perspectives of Antarctic history and geography because of the continent's lack of indigenous people and its extreme environment, but as Klaus Dodds, Sanjay Chaturvedi and Christy Collis have argued, these factors make Antarctic colonialism a fascinating special case. ${ }^{15}$

For adventurous and scientific Australians of the 20th century, two frontiers beckoned: the white desert and the red heart, the far south and the outback. Adelaide, where Mawson gained a lecturing post in his twenties, was sandwiched between these frontiers; it was a city exposed to the winds of both deserts. Mawson, Cecil Madigan, Charles Laseron, Edgeworth David, Griffith Taylor and Syd Kirkby ventured in both directions, and Baldwin Spencer and JW Gregory went inland after almost going south. A contemporary expeditioner of this kind is Peter Campbell, the Casey plant inspector and diesel mechanic on my voyage south in late 2002. Peter, who has a big red beard and hence is known

13 For an elaboration of these paragraphs and for the meaning of ice in the climate crisis, see Tom Griffiths (2010) 'A humanist on thin ice: science and the humanities, people and climate change'. Griffith Review 29, August: http://griffithreview.com/edition-29-prosper-or-perish/a-humanist-on-thin-ice.

14 Sydney Morning Herald article (1997) quoted on p. 22 of Christy Collis (2000) 'Mawson's hut: emptying post-colonial Antarctica'. Journal of Australian Studies 63: 22-29.

15 Klaus J Dodds (2006) 'Post-colonial Antarctica: an emerging engagement'. Polar Record 42, 220: 5970; Sanjay Chaturvedi (1996) The polar regions; a political geography. John Wiley, Chichester; Collis (2000) 'Mawson's hut'; and Christy Collis and Quentin Stevens (2007) 'Cold colonies: Antarctic spatialities at Mawson and McMurdo Stations', Cultural Geographies 14: 234-54. 
as 'Bloo', came from Humpty Doo in the Northern Territory. So he continued the Australian tradition of comparing blizzards to dust storms, and wrote for BushMag: Journal of the Outback about the similarities of his two frontiers, 'the white and red deserts' ${ }^{16}$ Bloo marked his mid-winter at Casey by adding the name of his tiny town to the tall pole outside the station indicating the direction and distances of settlements. It now reads: London 15,966; Bucharest 14,211; Hobart 3,424; Vostok 1,383; Humpty Doo 6,141 ...

Although inhabitants of an arid land may seem strange colonisers of the ice, Australians do know something about deserts. Christy Collis has argued that, in the 20th century, the Australian desert of the imagination - the place of imperial opportunity and continental conquest - effectively moved to Antarctica. ${ }^{17}$ Certainly there is a fascinating parallel cultural history of the two deserts to be teased out. Part of the sustained power for Australians of Douglas Stewart's radio play The Fire on the Snow (about Captain Scott's tragic polar expedition) must lie in this correspondence. Literary scholars have suggested that Australian writers like Stewart and Thomas Keneally (who wrote two novels inspired by heroic-era expeditions) use Antarctica as 'a surrogate land for Australia', as an alternative template for imagining a continental colonisation. ${ }^{18}$ Sidney Nolan, one of Australia's great artists of the mythic outback, relished the opportunity he gained in 1964 to paint the white desert. In the same year that he was working on his paintings of the lost inland explorers Burke and Wills, Nolan visited Antarctica and found it provided 'an intensification' of what he had experienced in the heart of his own country. ${ }^{19}$ It is not just a matter of Australians learning to look south and to secure their national interest there; it is also a story of Gondwanan cousins - one claimed by fire and the other by ice - providing vital, formative experiences of the frontier in a settler nation.

Mawson thought Antarctica might become an 'Alaska' to Australia's United States, a new frontier for a 'young' nation. ${ }^{20}$ Brigid Hains, in The ice and the inland, studied the lives of Douglas Mawson and John Flynn (of the Inland) to explore the myth of the frontier in a rapidly modernising Australian nation. She argued that for settler Australians of the early 20th century, anxious to assert a national identity and worried about the mental and physical effects of an urbanising population, the Antarctic frontier, like the outback, was a place

\footnotetext{
16 Bloo Campbell, 'Notes from the Antarctic desert', BushMag: Journal of the Outback, 2003 http://www. bushmag.com.au, viewed 1 November 2006.

17 Collis (2000) 'Mawson's hut', p. 24.

18 Elizabeth Leane (2007) 'A place of ideals in conflict: images of Antarctica in Australian literature'. In CA Cranston and Robert Zeller, eds, The littoral zone: Australian contexts and their writers. Rodopi, Amsterdam, pp. 261-89; Anthony Hassall (1988) 'Quests'. Australian Literary Studies 13(4): 390-408.

19 Rodney James (2006) Sidney Nolan: Antarctic journey. Mornington Peninsula Regional Gallery, Mornington [Vic].

20 Brigid Hains (2002) 'The graveyard of a century'. In Tim Bonyhady and Tom Griffiths, eds Words for country: landscape and language in Australia. UNSW Press, Sydney, pp. 124-39.
} 
of both anxiety and opportunity. There were concerns about the organic vitality of the race (especially in a young nation founded as a penal colony) and about the invigorating potential — but also degenerative effects - of the frontier. The harsh desert environments threatened regression but also offered renewal. 'To the white Australian imagination,' wrote Hains, 'the frontier was the place where civilization unravelled into wilderness - for good or ill. ${ }^{21}$

There was cultural as well as political theatre in Antarctic life. When BANZARE voyage members had their group photo taken at Commonwealth Bay in 1931, Mawson insisted that they 'all dress up for it and make it look cold'. ${ }^{22}$ Australians down south were journeying into the heart of another 'unclaimed' space, and testing and proving their national and racial qualities. To a settler people in an Aboriginal land there was an attractive moral simplicity about colonising an uninhabited continent, a true terra nullius. There was something redemptive about Antarctica's unalloyed whiteness.

And then, there is the silence calling. ${ }^{23}$ In this final section, I want to consider the silence and the sounds of Antarctica. The American biologist David Campbell, in his lyrical book The crystal desert, described terrestrial Antarctica as 'the antithesis of the Amazon ... It is like the silence between movements of a symphony'. In his effort to define the uniqueness of Antarctica, this scientist chose sound as his metaphor of difference. For David Campbell, Antarctica and the Amazon - the two primary sites of his biological fieldwork - are stunning opposites. The Amazon, he writes, is an inchoate green tapestry, an 'apex of earthly diversity'. 'Imagine', he says, 'there are more species of lichens, liverworts, mosses, and algae growing on the upper surface of a single leaf of an Amazonian palm than there are on the entire continent of Antarctica.' Antarctica, by contrast he explained, is 'parsimonious ... it is biological haiku'. But of course, Campbell goes on to acknowledge that Antarctica and the Amazon, however different, are both on the same blue planet, and are interactive in fascinating ways. Antarctica, in all its implacable, silent majesty, is 'also a key to the diversity of the tropics'. It is the weather factory and the global engine of climate that, over millions of years, has 'driven speciation in the distant tropics' ${ }^{24}$ Thus simplicity and diversity, silence and symphony, are connected; they are one.

21 Brigid Hains (2002) The ice and the inland: Mawson, Flynn, and the myth of the frontier. Melbourne University Press, Melbourne, p. 5.

22 Stuart Campbell, Diary, Mitchell Library, Sydney, Microfilm CY 4317, 5 January 1931.

23 The brilliant title of Tim Bowden's Antarctic history (1997) is The silence calling: Australians in Antarctica 1947-97. Allen \& Unwin, Sydney.

24 David G Campbell (1993) The crystal desert: summers in Antarctica. Minerva, London, p. 51, and (2005) A land of ghosts: the braided lives of people and the forest in far western Amazonia. Rutgers University Press, p. 12. 
Silence is one of the most common metaphors of Antarctic life and experience, and many of these papers explore it. It seems a paradox that the howling wilderness', or The home of the blizzard as Douglas Mawson called his foothold on the continent of ice, should be known for its silence. But, of course, the two are related as David Campbell knew, for the silence comes between the movements of the symphonic wind. Silence is a period of non-wind, and the power of silence is heightened by the memory of the blizzard. Indeed, it is the aftershock of wind that can give silence its resonance. Mawson himself put this very well. Listen to his words from The home of the blizzard as he seeks to analyse the experience of sound in Antarctica - he does so as a scientist (Mawson was always first the scientist) but there is also more than a little bit of the poet in him:

The climate [at Commonwealth Bay] proved to be little more than one continuous blizzard the year round; a hurricane of wind roaring for weeks together, pausing for breath only at odd hours. Such pauses - lulls of a singular nature - were a welcome relief to the dreary monotony, and on such occasions the auditory sense was strangely affected. The contrast was so severe when the racking gusts of an abating wind suddenly gave way to intense, eerie silence that the habitual droning of many weeks would still reverberate in the ears. At night one would involuntarily wake up if the wind died away and be loth to sleep 'for hunger of a sound'. In the open air the stillness conveyed to the brain an impression of audibility, interpreted as a vibratory murmur. ${ }^{25}$

Mawson is here talking of the contrast between sound and silence, and about the auditory memory of wind. But during his two years at Commonwealth Bay, he learned that there was another source of distant droning, of muffled roaring. It was not just the memory of wind that was ringing in his ears. Mawson and his men gradually realised that, on the rare days when their own hut by the bay was becalmed, the ferocious katabatic wind continued to blow as usual about a thousand feet above them. As Mawson put it, 'So we came to realize that when a calm fell upon the Hut, the wind had merely retired to higher elevations and hung over us like the sword of Damocles, ready to descend at any moment. ${ }^{26}$ This was the source of 'an incessant, seething roar' that they heard so constantly.

No continent is more dominated by wind than Antarctica. At Commonwealth Bay, the meteorologist Cecil Madigan left memorable descriptions of his work recording a continental weather pattern ruled by wind. In 1912, complete weather observations were taken every six hours. All data was entered in

25 Douglas Mawson (1996) The home of the blizzard [originally published in two volumes in 1915]. Wakefield Press, Adelaide, p. 77. Some of the poetics were contributed by the expedition doctor Archibald McLean, with whom Mawson collaborated in the writing of the book.

26 Mawson (1996) The home of the blizzard, p. 78. 
pencil in a meteorological day book, and 15 of these 100-page books were filled. Visiting the anemometer was, admitted Madigan, 'physically a fairly severe undertaking, presenting considerable difficulty in the mere finding of it'. He goes on to explain:

After some practice the members of the expedition were able to abandon crawling, and walked on their feet in these 90 mile torrents of air, 'leaning on the wind'... I found that in a 90-mile wind, if I faced it and kept the body straight, I could touch the ground in front by extending an $\operatorname{arm} .{ }^{27}$

Mastery of this 'hurricane-walking', as they called it, became an essential meteorological accessory. Just as the silence would roar in people's ears, and just as they would wake up when the blizzard died, so did people fall over when the wind stopped.

I have been depicting silence as a function of wind, silence as an absence. But silence itself has a texture and a timbre; it can roar in one's ears all on its own. The silence is palpable in Antarctica. It is a presence, not merely an absence. Carsten Borchgrevink, leading the first party to winter on the land in Antarctica, wrote in 1899 that 'The silence roared in our ears, it was centuries of heaped-up solitude. ${ }^{28}$ The American explorer Richard Byrd wrote in his diary in December 1928, after his first night on the continent, that 'It is as quiet here as in a tomb. Nothing stirs. The silence is so deep one could almost reach out and take hold of it.' American nature writer, Barry Lopez, when visiting the dry valleys, described 'a silence dense as water'.

And sometimes the silence could be exhilarating. Byrd's geologist, Laurence McKinley Gould, wrote in praise of the Antarctic silence:

When there is no wind this is a land of unparalleled quiet. But it is a different quiet than one feels back home. I have stood in the woods at home when the world seemed dead. There was no kind of sound. But in that world where a variety of sound was the rule rather than the exception such a silence was oppressive if not ominous. Not so here this is a land of silence. One stands in the midst of it without any feeling of oppressiveness. It is an expanding sort of silence. It is inviting. It is the natural state here and I like it - I have come to feel at home in the midst of it. ${ }^{29}$

27 Cecil T Madigan (1929) 'Tabulated and reduced records of the Cape Denison station', 'Adelie Land'. In Australasian Antarctic Expedition 1911-14, Scientific Reports, Series B, vol IV, Meteorology. Alfred J. Kent, Government Printer, Sydney, p. 20.

28 Janet Crawford (1998) That first Antarctic winter. South Latitude Research Ltd, in association with Peter J Skellerup, Christchurch, p. 112.

29 Laurence McKinley Gould (1931) COLD: the record of an Antarctic sledge journey. Brewer, Warren \& 
In 1934, on his second expedition, the American aviator Richard Byrd tried an awesome, dangerous and near-fatal experiment on himself. For four dark months of the polar winter, he lived alone at the Bolling Advance Weather Base on the Ross Ice Shelf at $80^{\circ} \mathrm{S}$. He found the silence of the Barrier enthralling:

I have never known such utter quiet. Sometimes it lulled and hypnotised, like a waterfall or any other steady, familiar sound. At other times it struck into the consciousness as peremptorily as a sudden noise. It made me think of the fatal emptiness that comes when an airplane engine cuts out abruptly in flight. Up on the Barrier it was taut and immense; and, in spite of myself, I would be straining to listen - for nothing, really, nothing but the sheer excitement of silence. ${ }^{30}$

Morton Moyes, a meteorologist on Mawson's 1911-14 expedition, spent nine weeks alone in Queen Mary Land in 1912-13, awaiting the return of sledging parties. He documented the silence in his diary. November 7: 'All alone here now and the silence is immense.' December 20: 'The Silence is so painful now that I have a continual singing in my left ear, much like a Barrel Organ, only it's the same tune all the time.'31 When his companions returned and broke the silence, Morton Moyes stood on his head for joy.

Returning penguins could bring similar pleasure. Charles Laseron, one of Mawson's expeditioners, wrote: 'No longer, when it was calm, did the ears throb with the silence, the raucous cries of the penguins filled the air to the exclusion of everything else'. He elaborated on this weird sensation of his ears throbbing with silence:

In the middle of lunch we all become aware of something strange. Our ear-drums commence to throb as with a great noise. Somebody speaks and his voice cracks like a whip on the stillness. For the wind has stopped, and, accustomed as we are to its howl, the silence can literally be felt. For a while we speak almost in whispers, our heads are ringing and we feel very uncomfortable ... And the intense, utter silence - it seems as if the whole world is dead. The tinkling of a piece of ice falling in the distance rings out like a thunder-clap. ${ }^{32}$

Louis Bernacchi, the Tasmanian scientist on Borchgrevink's expedition, looked inland across the continent from Cape Adare and this is what he saw:

The silence and immobility of the scene was impressive; not the slightest animation or vitality anywhere. It was like a mental image of our globe in its primitive state - a spectacle of Chaos.

30 Richard Byrd (1938) Alone. Putnam, London, p. 120.

31 Morton Henry Moyes, Diary, Mitchell Library, Sydney, ML MSS 388/1, CY 3660.

32 Charles Laseron (1947) South with Mawson. Australasian Publishing Company, Sydney, p. 78. 
Around us ice and snow and the remnants of internal fires; above, a sinister sky; below, the sombre sea; and over all, the silence of the sepulchre! ${ }^{33}$

Bernacchi felt that he was looking not just at ice-age Earth, at his world in the deep past of the Pleistocene, but also at the bleak future of his planet, spinning cold in space.

We can see that some of these metaphors of silence are those of death - 'the silence of the sepulchre', 'this everlasting silence'. This silence is not that between the movements of a symphony, but comes at its end. Antarctica sometimes seems to provide an experience of life on Earth before and after us, even an experience of Earth before and after Life itself.

The Antarctic silence was the space within which other, surprising sounds could be heard - the beating of one's heart, perhaps, or the thump of your very own pulse in your temples. It was said that Frank Wild had such a strong heart and booming chest that, if you happened to share a sleeping bag with him, you would be kept awake all night by the beating of his heart. Frederick Cook, the doctor on the Belgian Antarctic Expedition of 1897-98, the first to winter in Antarctica, speculated that the sun seemed to provide something that steadied the human heart. The absence of the sun, he reported, registered in the internal disorder of his fellow expeditioners. Mitral murmurs became audible, resounding loudly in the silence of the polar night.

And what of the peculiar rhythm and ache of the continent of ice itself? In 1987, Greenpeace established a World Park Base on Ross Island, and Gudrun Gaudian, the only woman staying for the winter, relished what she called the 'vast, white silence' of the place. Sometimes the only sound she could hear in the autumn was the creaking of the thickening ice in the bay as the tide moved beneath it: 'It makes an eerie sound, just like an old door in a secret castle being opened very slowly.' ${ }^{34}$

When I visited Antarctica, I yearned to hear the ice creak and to escape the throb and thrum of engines - even the ship at rest, at anchorage, was constantly drumming, cranking and sighing in order to sustain the community on board. The station hummed with its own technology. At McMurdo in high summer, the only thing that distinguishes night and day is a slowing of the pace and a slight diminishing of machine noise. ${ }^{35}$

33 Louis Bernacchi (1901) To the South Polar Regions: expedition of 1898-1900. Hurst \& Blackett, London, p. 78.

34 Gudrun Gaudian, 29 March 1987, in John May (1989) The Greenpeace book of Antarctica. Child \& Associates, Frenchs Forest, NSW, p. 164.

35 Bill Green (1995) Water, ice and stone: science and memory on the Antarctic lakes. Harmony Books, New York, p. 50. 
In Werner Herzog's wonderful film about Antarctica, Encounters at the end of the World (2007), one of his 'professional dreamers' talks beautifully about 'the rumble of the iceberg'. Douglas MacAyeal, a glaciologist, waxes lyrical about B15, the great berg he is studying, and he says: 'I can feel the rumble of the iceberg. I can feel the change, the cry of the iceberg as it's screeching and as it's bouncing off the sea bed, as it's steering the ocean currents, as it's beginning to move north. I can feel that sound coming up through the bottoms of my feet.'

And then Herzog introduces us to Regina Eisert, a physiologist living on the sea ice and studying Weddell seals. She says:

It's the quietest place. When the wind is down or there's no wind, it wakes you up in the middle of the night. And if you walk out on the ice you hear your own heart beat, that's how still it is. And you can hear the ice crack, and it sounds like there's someone walking behind you but it's just the ice, these little stress cracks moving all the time. And you can hear the seals call and it's the most amazing sound, really inorganic — it sounds like Pink Floyd or something - they don't sound like animals.

It is that ocean under the ice - 'the world under the frozen sky', as Herzog calls it - which becomes the poetic heart of the film. People speak of entering that world as 'going down into the cathedral'. One of the film's quirkiest images is that of three scientists lying on the sea ice listening to the music of the underworld, ears pressed to the frozen surface of the ocean. The camera lingers long on this spectacle. The people are prone as if in prayer, and they are alert, their every sense attentive to sound.

That image of humans thoughtfully in thrall to another world will serve for me as a beautiful symbol of the conference. Art and science are indistinguishable in the contemplation of wonder and the quest for understanding. This is what we are doing here together - pressing our ears to the ice, tuning into Antarctic sounds, and ultimately taking the heartbeat of the planet. ${ }^{36}$

36 In sections of this paper, I have drawn on my 2007 book Slicing the silence: voyaging to Antarctica (UNSW Press, Sydney), and my contributions to the edited collection of Haward and Griffiths (2011) Australia and the Antarctic Treaty system. 
This text is taken from Antarctica: Music, sounds and cultural connections, edited by Bernadette Hince, Rupert Summerson and Arnan Wiesel, published 2015 by ANU Press, The Australian National University, Canberra, Australia. 